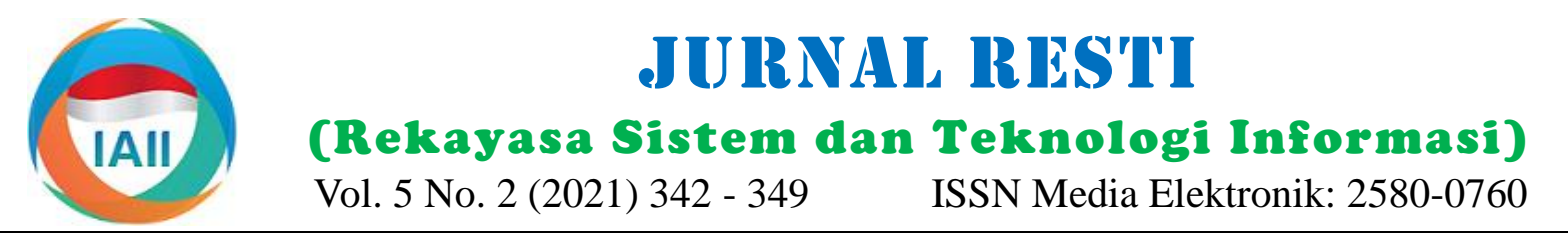

\title{
Evaluasi Parameter RAW Berdasarkan Multirate Pada IEEE 802.11ah: Simulasi Kinerja Optimum Jaringan IoT
}

\author{
Haris Mustaqin ${ }^{1}$, Teuku Yuliar Arif ${ }^{2}$, Rizal Munadi $^{3}$ \\ ${ }^{1,2,3}$ Magister Teknik Elektro, Universitas Syiah Kuala \\ 1'haris.mustaqin@unsyiah.ac.id*, ${ }^{2}$ yuliar@unsyiah.ac.id, ${ }^{3}$ rizal.munadi@unsyiah.ac.id
}

\begin{abstract}
IEEE 802.11ah WLAN is a technology standard for IoT networks because it can provide a higher transmission range and data rate than WPAN and LPWAN. To manage channel access up to 8191 at the MAC layer IEEE 802.11ah a Restricted Access Window scheme was introduced. Generally, evaluation and optimization of RAW parameters are only based on constant data rates without taking into account the mutirate support for PHY AP and STA IoT IEEE 802.11ah. This study uses an open source-based NS-3 network simulator. Simulation analysis is run by calculating the value of throughput, delay, packet loss, and energy consumption of each node. Based on testing the effect of the number of slots on throughut, it shows that the resulting throughput values fluctuate with stable dominance, depending on the number of slots used. The effect of the number of slots on packet loss shows that the packet loss value is low for each slot because more packets can be accommodated in the $R A W$ slot queue. The effect of the number of slots on energy consumption decreases at some data rates and some lower energy consumption values, thereby saving energy consumption.
\end{abstract}

Keywords: multirate, restricted access window, throughput, delay, packet loss, IoT

\begin{abstract}
Abstrak
WLAN IEEE 802.11ah merupakan standar teknologi untuk jaringan IoT karena mampu menyediakan jangkauan transmisi dan data rate lebih tinggi dari WPAN dan LPWAN. Untuk mengatur akses kanal hingga 8191 pada lapisan MAC IEEE 802.11ah diperkenalkan skema Restricted Access Window (RAW). Literatur sebelumnya evaluasi dan optimasi parameter RAW hanya berdasarkan data rate konstan tanpa memperhitungkan dukungan mutirate pada PHY AP dan STA IoT IEEE 802.11ah. Penelitian ini bertujuan mengevaluasi dan menganalisis parameter RAW optimal, yaitu parameter Slot Duration Count, Number of Slots, dan RAW Group berdasarkan multirate untuk dapat menghasilkan kinerja WLAN IEEE 802.11ah yang optimal. Penelitian ini menggunakan simulator jaringan NS-3 berbasis open source. Prosedur pengujian dengan mengimplementasikan tahapan RAW berdasarkan multirate pada IEEE 802.11 ah untuk optimasi kinerja jaringan IoT. Analisis simulasi dijalankan dengan menghitung nilai throughput, delay, packet loss dan konsumsi energi masing-masing node. Berdasarkan pengujian pengaruh jumlah slot terhadap throughput menunjukkan nilai throughput yang dihasilkan berubah-ubah dengan dominasi stabil, tergantung jumlah slot yang digunakan. Pengaruh jumlah slot terhadap delay cenderung stabil dan beberapa nilai delay juga rendah, rata-rata delay dipengaruhi oleh mekanisme RAW dimana saat paket dikirim tetapi belum mendapat kesempatan pada bagian RAW slot. Pengaruh jumlah slot terhadap packet loss menunjukkan nilai packet loss rendah tiap slot-nya, dikarenakan lebih banyak paket yang dapat ditampung pada antrian $R A W$ slot. Pengaruh jumlah slot terhadap konsumsi energi menurun pada beberapa data rate dan beberapa nilai konsumsi energi lebih rendah sehingga menghemat konsumsi energi. Hal diakibatkan dengan bertambahnya jumlah slot kecepatan mobilitas meningkat, namun nilai rata-rata konsumsi energi hanya naik sedikit.
\end{abstract}

Kata kunci: Multirate, Restricted Acces Windows, Throughput, Delay, Packet Loss, IoT

\section{Pendahuluan}

Standar Wi-Fi IEEE 802.11ah secara resmi dirilis pada tahun 2016. Perangkat ini beroperasi dengan kecepatan data mulai dari $150 \mathrm{Kbps}$ hingga 78 Mbps dalam satu aliran spasial [1]. Studi terbaru menunjukkan bahwa
IEEE 802.11ah lebih hemat energi daripada IEEE 802.15.4 karena lebih sedikit overhead pensinyalan, meningkatkan masa pakai baterai hingga 6 kali [2]. Wireless Local Area Network (WLAN) IEEE 802.11ah merupakan standar teknologi yang potensial digunakan

Diterima Redaksi: 17-02-2021 | Selesai Revisi: 18-04-2021 | Diterbitkan Online: 30-04-2021 
untuk jaringan Internet of Things (IoT) karena mampu Pada beberapa penelitian, parameter $R A W \quad$ telah menyediakan jangkauan transmisi dan data rate jauh dioptimalisasi menggunakan pendekatan yang berbeda. lebih tinggi dari Wireless Personal Area Network Pendekatan pertama menggunakan model analitikal [8](WPAN) dan Low Power Wide Area Network [11]. N. Nawaz, dkk. [8] mengevaluasi dan (LPWAN). Teknologi WPAN seperti Bluetooth dan mengoptimalkan parameter durasi slot RAW Zegbee memiliki data rate hingga $1 \mathrm{Mbps}$, namun jarak berdasarkan nilai parameter RAW Group. Gopinath dan jangkau hanya sampai 100 meter. Sebaliknya teknologi Nithya [9] mengusulkan metode Fungsi Koordinasi LPWAN seperti LoRAWAN dan SigFox memiliki jarak Terdistribusi (DCF) yakni metode akses media berbasis jangkau hingga $40 \mathrm{~km}$, namun hanya mendukung data contention yang menggunakan Binary Exponential rate hingga $25 \mathrm{kbps}$ [3]. Selain itu, WLAN IEEE Backoff (BEB) untuk menyelesaikan contention antara 802.11ah mampu mengkoneksikan hingga 8191 stasiun di dalam RAW Group. R. Wang, dkk [10] perangkat IoT pada satu Access Point (AP) yang sama mengevaluasi dan mengoptimalkan parameter $R A W$ sehingga sangat sesuai untuk berbagai aplikasi IoT.

WLAN IEEE 802.11ah terdiri dari 2 lapisan, lapisan Fisik (PHY) dan lapisan Kontrol Akses Sedang (MAC). PHY 802.11ah dirancang dengan menggunakan operasi down-clocked pada IEEE 802.11n, sehingga memiliki mode distribusi bandwidth saluran $2 \mathrm{MHz}, 4 \mathrm{MHz}, 8$ $\mathrm{MHz}, 16 \mathrm{MHz}$, dan satu bandwidth saluran tambahan 1 MHz. [4] Lapisan Physical (PHY) IEEE 802.11ah beroperasi pada pita frekuensi sub-1 GHz dan memungkinkan jarak transmisi antara $100 \mathrm{~m}$ hingga 1 $\mathrm{km}[5]$.

Group berdasarkan pengelompokan hidden node, dimana informasi hidden node dikumpulkan pada saat proses asosiasi semua STA. Sedangkan AP. Y. Wang, dkk. [11] mengevaluasi dan mengoptimalkan parameter $R A W$ Group untuk meningkatkan efisiensi energi dan menurunkan delay berdasarkan teori Markov Chain. Namun penggunaan model analitikal tersebut membutuhkan proses komputasi yang tinggi sehingga sulit dieksekusi secara real-time pada perangkat AP yang memiliki sumber daya terbatas. Oleh sebab itu AP harus dapat menentukan secara tepat nilai parameter RAW, yaitu Slot Duration Count, Number of Slots, dan

Untuk mengatur akses kanal hingga 8191 perangkat IoT, pada lapisan Medium Access Control (MAC) IEEE 802.11ah diperkenalkan skema Restricted Access Window $(R A W)$ [6]. Skema ini digunakan oleh Access Point (AP) untuk membatasi akses kanal kepada kelompok perangkat IoT station (STA) tertentu agar tingkat perebutan akses kanal menurun dan kinerja jaringan bisa meningkat. Dalam skema RAW, AP membroadcast frame beacon yang berisi informasi $R A W$ Parameter Set (RPS). Opsi ini disebut cross slot boundary (batas slot silang) dengan menyiapkan satu bit khusus (disebut sub bidang cross slot boundary) dalam elemen RPS yang di-broadcast oleh AP dalam frame beacon, tujuannya termasuk untuk meminimalisir terjadinya collisions [7]. Dalam RPS terdapat nilai parameter RAW penting yaitu Slot Duration Count, Number of Slots, dan RAW Group. Dalam dokumen standar IEEE 802.11ah tidak ditentukan bagaimana perhitungan masing-masing nilai parameter tersebut untuk menghasilkan kinerja jaringan IEEE 802.11ah yang optimal. sehingga.

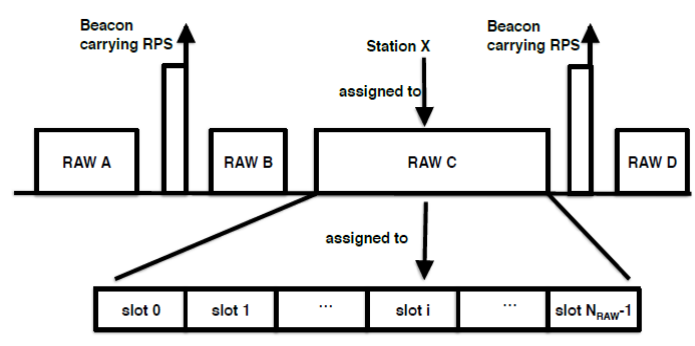

Gambar 1. Mekanisme Skema $R A W[10]$

\begin{abstract}
Beberapa peneliti lain mengevaluasi dan mengoptimalkan paramater RAW berdasarkan proses komputasi yang lebih sederhana seperti dalam paper [11]-[14]. L. Tian, dkk. [12] mengevaluasi pengaruh parameter beban trafik, jumlah STA dan durasi RAW terhadap jumlah optimal RAW Group. M. N. Perbawa, dkk. [13] mengevaluasi parameter RAW optimal dengan mempertimbangkan parameter Enhance Distributed Channel Access (EDCA). A. Sljivo, dkk [14] mengevaluasi parameter RAW optimal berdasarkan kondisi trafik dua arah. L. Tian, dkk. [15] mengusulkan model pengganti yang memprediksi kinerja RAW berdasarkan kondisi jaringan tertentu dan berdasarkan konfigurasi parameter RAW. Namun evaluasi dan optimasi parameter RAW yang telah diusulkan oleh literatur-literatur tersebut hanya berdasarkan data rate konstan tanpa memperhitungkan dukungan mutirate pada PHY AP dan STA IoT IEEE 802.11ah.
\end{abstract}

\section{Metode Penelitian}

Penelitian ini menggunakan metode eksperimental menggunakan simulator jaringan NS-3 berbasis open source. Source code NS-3 bisa diunduh langsung dari web NS-3 (www.nsnam.org). Penelitian ini dilakukan untuk mengevaluasi parameter Slot Duration Count, Number of RAW Slots, RAW Duration, dan RAW Group untuk menghasilkan kinerja WLAN IEEE 802.11ah yang optimal multirate pada IEEE 802.11ah yang pengembangannya menggunakan simulator NS-3 sehingga dapat diimplementasikan pada 802.11ah.

DOI: https://doi.org/10.29207/resti.v5i2.2961

Lisensi: Creative Commons Attribution 4.0 International (CC BY 4.0) 
Metode penelitian yang digunakan berupa simulasi dalam Tabel 1 dan Tabel 2. Parameter MAC dan PHY untuk menguji tingkat keberhasilan dan kegagalan tersebut sesuai standar IEEE 802.11ah [18] sistem sehingga hasil dapat dianalisis dan disimpulkan. Optimasi parameter Page Period, Page Slice Length dan Page Slice Count berdasarkan multirate. menggunakan aplikasi NS-3 dari hasil tersebut dapat menghitung optimasi kinerja jaringan IoT dengan cara menghitung throughput, delay, packet loss dan konsumsi energi masing-masing node dan dilakukan evaluasi serta analisis untuk menentukan optimasi kinerja. Pada evaluasi ini digunakan skenario simulasi menggunakan parameter MAC dan PHY simulasi dijalankan 10 kali, selanjutnya dihitung rata-rata total waktu registrasi dan standar deviasinya. Adapun tahapan yang dilakukan untuk mengevaluasi parameter $R A W$ pada IEEE 802.11ah untuk meningkatkan efisiensi energi jaringan IoT.

\subsection{Prosedur Pengujian}

Prosedur pengujian yang dilakukan adalah dengan cara mengimplementasikan tahapan Restricted Access Window berdasarkan Multirate pada IEEE 802.11ah untuk optimasi kinerja jaringan IoT pada aplikasi simulator NS-3. Adapun bahan penelitian yang diperlukan untuk melakukan penelitian ini adalah Modul IEEE 802.11 ah yang telah dikembangkan oleh literature [16] dan data plot grafik perbandingan penggunaan energi dan throughput. Kemudian menganalisa throughtput, delay, packet loss dan konsumsi energi yang dihasilkan berdasarkan multirate pada WLAN 802.11ah.

Untuk mengevaluasi pengaruh Restricted Access Window berdasarkan Multirate pada IEEE 802.11ah, penelitian ini menggunakan modul IEEE 802.11ah yang telah dikembangkan oleh L. Tian, dkk dalam simulator jaringan NS-3 [17]. Dalam simulasi, AP ditempatkan di titik pusat area lingkaran dengan radius maksimum $80 \%$ dari jangkauan data rate ke AP yakni $1 \mathrm{~km}$ dan setiap $100 \mathrm{~ms}$ AP mem-broadcast frame beacon yang dapat diterima oleh seluruh $N$ node. Jumlah $N$ node terkecil dalam simulasi ini adalah 128 node. Masing-masing node dalam periode beacon memiliki bilangan random $U_{R} \leq V_{A C T}$ yang akan memperebutkan akses kanal untuk melakukan proses registrasi dengan mentransmisikan frame AuthReq/AssocReq ke AP menggunakan data rate constant yang dimulai dengan Modulation and Coding Scheme (MCS) dalam hal ini mnggunakan MCS0 dan bandwidth kanal $1 \mathrm{MHz}$. Node kemudian mengirim paket pada AP selanjutnya dihitung throughput, delay, packet loss dan konsumsi energi masing-masing node. Penulis mengulangi simulasi menggunakan data rate constant yang sama namun
dengan jumlah node yang berbeda, yaitu 256,512 dan 1024 node.

Dalam skenario simulasi, penulis menggunakan parameter MAC dan PHY seperti yang diperlihatkan

Tabel 1. MAC Layer Parameter Used in Simulations [3][9]

\begin{tabular}{lr}
\hline \multicolumn{1}{c}{ Parameters } & Value \\
\hline Beacon length & $67 \sim 100$ bytes \\
Authentication request length & 26 bytes \\
Authentication response length & 24 bytes \\
Association request length & 37 bytes \\
Association response length & 27 bytes \\
Authentication request timeout & $500 \mathrm{~ms}$ \\
Association request timeout & $500 \mathrm{~ms}$ \\
AuthReqAck/ ACK length & 14 bytes \\
Management Queue Threshold & 10 \\
Step size of ACT & 50 \\
Backoff slot duration & $52 \mu \mathrm{s}$ \\
SIFS & $160 \mu \mathrm{s}$ \\
DIFS & $264 \mu \mathrm{s}$ \\
Beacon interval & $100 \mu \mathrm{s}$ \\
Backoff slots & 32 \\
Retry limit & 7 \\
\hline
\end{tabular}

Tabel 2. PHY Layer Parameters Used in Simulations [3][9]

\begin{tabular}{lr}
\hline \multicolumn{1}{c}{ Parameters } & Value \\
\hline AP's transmission range & 1000 meters \\
IoT device's transmission range & 500 meters \\
IoT device position & random \\
Carrier frequency & $900 \mathrm{MHz}$ \\
Channel bandwidth & 1 and $2 \mathrm{MHz}$ \\
PHY rate & Thbs $~ 7.8 \mathrm{Mbps}$ \\
PHY heaser + preamble & $20 \mu \mathrm{s}$ \\
AP's transmission power & $30 \mathrm{dBm}$ \\
IoT device's transmission power & $1 \mathrm{dBm}$ \\
AP's transmission gain & $3 \mathrm{dBi}$ \\
IoT device's transmission gain & $1 \mathrm{dBi}$ \\
AP's reception gain & $3 \mathrm{dBi}$ \\
IoT device's reception gain & $1 \mathrm{dBi}$ \\
Number of Tx/Rx antenna & $1 / 1$ \\
Guard time (GT) and IFG & $52 \mu \mathrm{s}$ \\
Air propagation delay & $3 \mu \mathrm{s}$ \\
Propagation loss model & Outdoor, macro \\
Error rate model & YansErrorRate \\
\hline
\end{tabular}

\subsection{Analisis Hasil Simulasi}

Analisis simulasi yang dilakukan pada evaluasi parameter RAW berdasarkan multirate pada IEEE 802.11ah untuk optimasi kinerja jaringan IoT yaitu menghitung throughput, delay, packet loss dan konsumsi energi masing-masing node dan dilakukan evaluasi serta analisis untuk menentukan optimasi kinerja. Pada evaluasi ini digunakan skenario simulasi menggunakan parameter MAC dan PHY simulasi dijalankan 10 kali sehingga penulis bisa menghitung rata-rata total waktu registrasi dan standar deviasinya.

\section{Hasil dan Pembahasan}

Setelah dilakukan simulasi dengan aplikasi simulator NS-3 maka diperolehkan hasil berupa throughput, delay, packet loss dan konsumsi energi masing-masing node dan dilakukan evaluasi serta analisis untuk menentukan optimasi kinerja. 
3.1. Pengaruh jumlah slot terhadap throughput

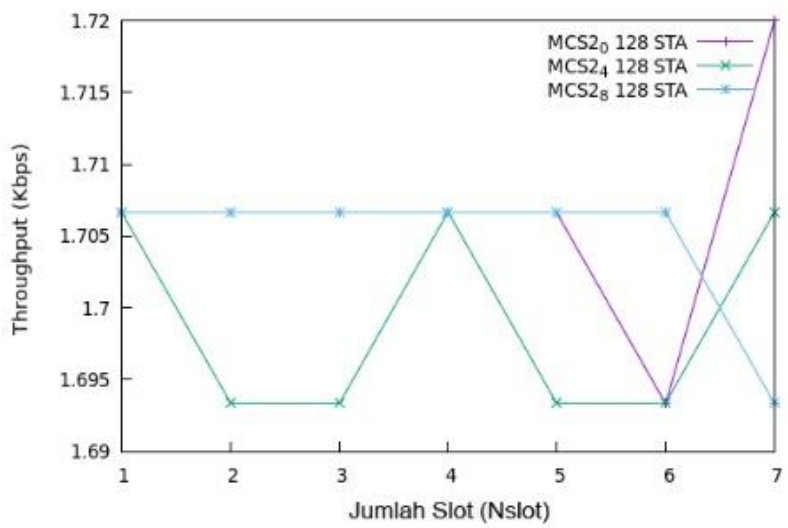

Gambar 2. Hasil simulasi Throunghput (Kbps) berdasarkan Jumlah $R A W$

Berdasarkan Gambar 2 menunjukkan hubungan antara throughput terhadap jumlah slot (N Slot). Throughput mengukur secara nyata seberapa cepat suatu data dikirim pada jaringan. Nilai throughput yang dihasilkan pada data rate yang menggunakan bandwidth $2 \mathrm{Mhz}$ dan indek MCSnya 4 atau MCS2_4 128 STA dan MCS2_8 128 STA adalah sama, sebesar 1,706 kbps hanya pada jumlah slot 1 dan 4. Perubahan jumlah slot memiliki efek terhadap performansi jaringan, dalam hal ini adalah performansi throughput. Pembagian atau pengelompokkan station ke dalam beberapa kelompok dalam satu $R A W$ group dapat digunakan untuk meminimalisir terjadinya contention antar jumlah slot dalam satu $R A W$ group dan mengurangi probabilitas terjadinya collision yang dapat menyebabkan turunnya performansi jaringan [19].

Throughtput diukur dalam bit per detik (bps). Throughtput sifatnya adalah dinamis tergantung pada trafik yang sedang terjadi. Semakin tinggi nilai pada throughtput, maka jaringan memiliki performa yang lebih baik. Nilai throughput yang dihasilkan pada MCS2_0 128 STA dan MCS2_8 128 STA adalah sama, sebesar 1,706 kbps hanya pada jumlah slot 5. Nilai throughput pada MCS2_8 128 STA memiliki nilai yang stabil yaitu 1,706 kbps untuk jumlah slot 1-6. Nilai throughput pada MCS2_4 128 STA, memiliki nilai yang berubah-ubah pada jumlah slot 1-6.

Jika dibandingkankan untuk ketiga jenis data rate tersebut MCS2_8 128 STA memiliki Nilai throughput yang lebih bagus bila dibandingkan dengan MCS2_0 128 STA dan MCS2_4 128 STA. Hal ini dikarenakan MCS2_8 128 STA memiliki nilai indeks yang lebih tinggi, dan kualitas salurannya pun lebih baik dari yang lainnya.

Berdasarkan Gambar 3 MCS2_4 256 STA memiliki nilai throughput yang stabil di $3.42 \mathrm{Kbps}$ pada slot 4 - 7, dan MCS2_0 256 STA memiliki nilai throughput yang stabil di 3.4 Kbps pada slot 1 - 4. Hanya pada MCS2_8
256 STA yang memiliki nilai throughput yang berubahubah.

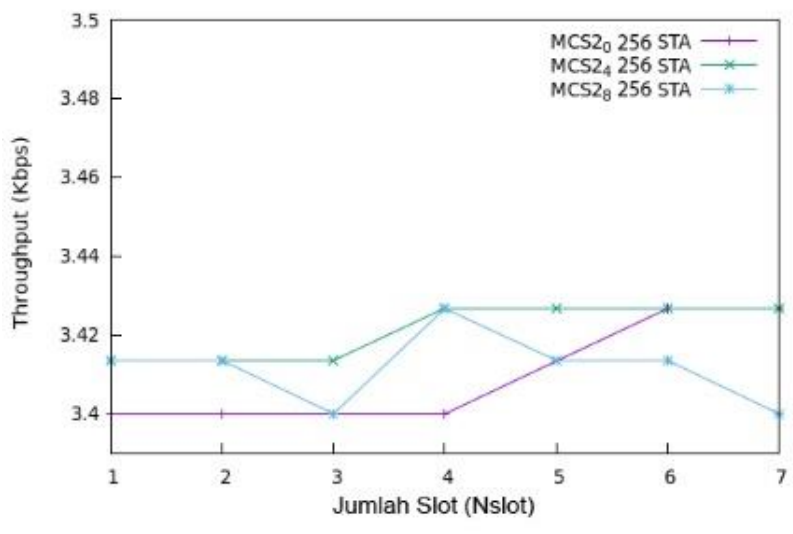

Gambar 3. Hasil simulasi 22-42 Throughput (Kbps) berdasarkan Jumlah $R A W$

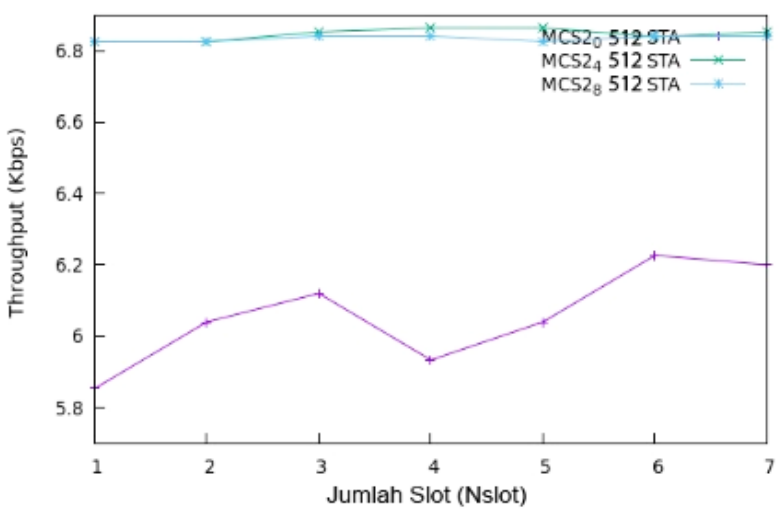

Gambar 4. Hasil simulasi 43-63 Throughput (Kbps) berdasarkan Jumlah $R A W$

Berdasarkan Gambar 4 diatas MCS2_4 512 STA dan MCS2_8 512 STA memiliki nilai throughput yang paling stabil berkisar $6.8 \mathrm{Kbps}$. Nilai throughput paling tinggi dihasilkan oleh MCS2_4 256 STA pada slot 4 dan 5. Sementara itu MCS2_0 512 STA memiliki nilai throughput yang tidak stabil dan merupakan yang paling rendah dibandingkan data rate lainnya.

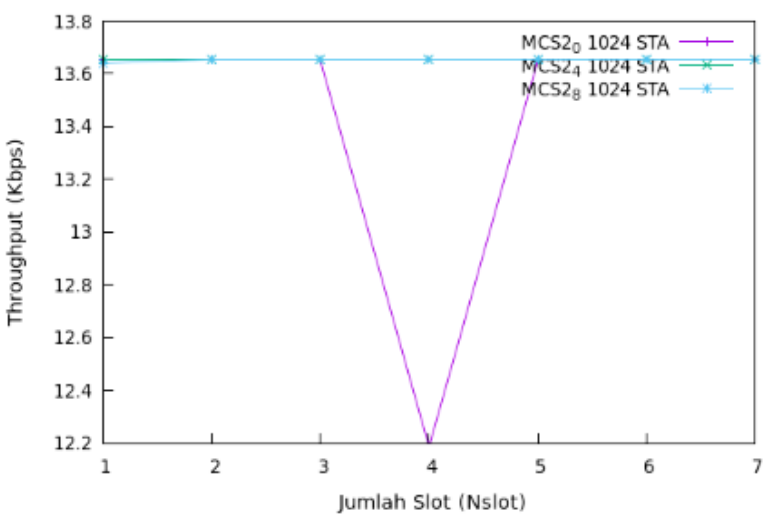

Gambar 5. Hasil simulasi 64-84 Throughput (Kbps) berdasarkan Jumlah $R A W$

DOI: https://doi.org/10.29207/resti.v5i2.2961

Lisensi: Creative Commons Attribution 4.0 International (CC BY 4.0) 
Berdasarkan Gambar 5 ketiga data rate memiliki nilai dibandingkan 2 data rate lainnya, terutama pada slot 3 throughput yang sama pada setiap slotnya, hanya pada dan 4, dimana waktu delaynya mencapai 2800ms MCS2_0 1024 STA slot 4 yang berbeda dan merupakan yang terendah nilai throughputnya pada proses pengujian. Hal ini kemungkinan diakibatkan data rate pada saat itu dalam kondisi sleep.

\subsection{Pengaruh jumlah slot terhadap delay}

Semakin besar perubahan delay dan packet lost maka proses transfer data akan menjadi semakin cepat. Delay merupakan waktu tunda yang dibutuhkan data untuk menempuh jarak dari asal hingga mencapai tujuan pada pengiriman data. Delay dapat dipengaruhi oleh jarak, media fisik, kongesti atau juga waktu proses yang lama. Pengaruh jumlah slot terhadap delay seperti yang diperlihatkan pada Gambar 6 - 9. Mengunakan sistem operasi linux ubuntu dengan aplikasi simulator NS-3 mendapatkan hasil sebagai berikut :

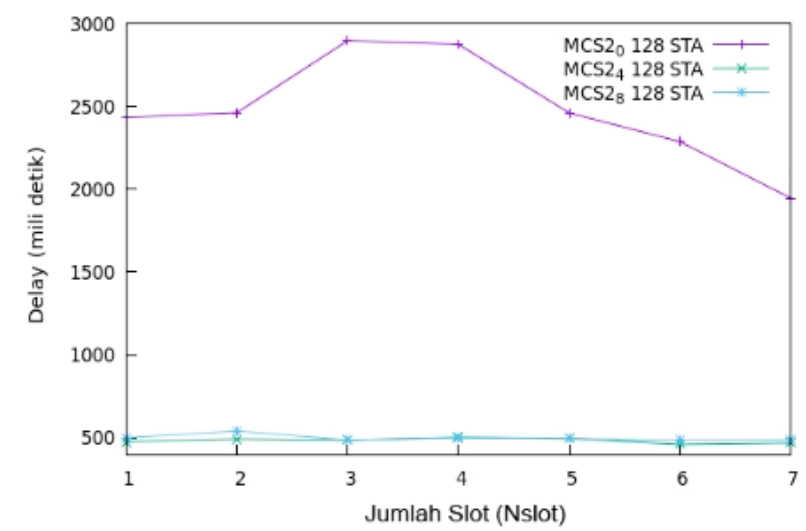

Berdasarkan Gambar 7 MCS2_8 256 STA memiliki delay paling besar yaitu $1200 \mathrm{~ms}$ pada slot 5 , sementara itu MCS2_0 256 STA yang paling stabil mulai dari slot 1 - 7 memiliki delay yang tidak berubah sebesar $0 \mathrm{~ms}$.

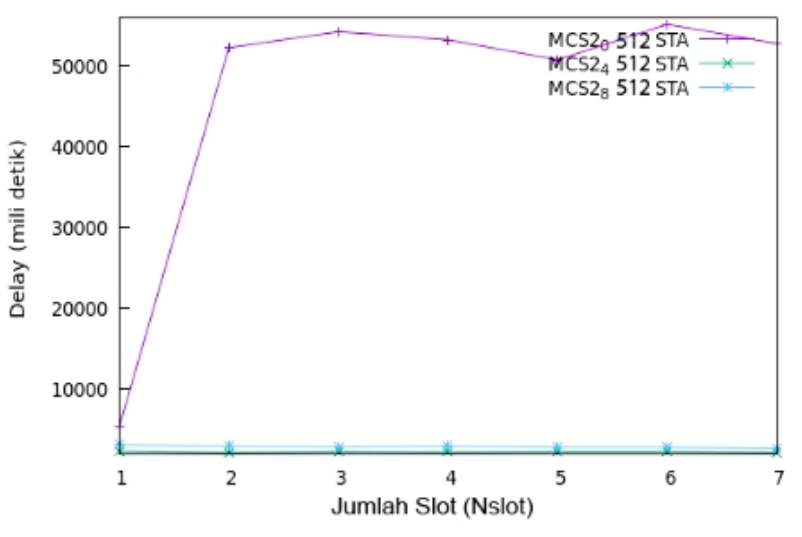

Gambar 8. Hasil simulasi 43-63 Delay (mili detik) berdasarkan Jumlah $R A W$

Berdasarkan Gambar 8 MCS2_0 512 STA slot 1 memiliki waktu delay $5319.1 \mathrm{~ms}$, namun mulai meningkat drastis mulai slot 2 dan memiliki delay paling besar yaitu $55183.91 \mathrm{~ms}$ pada slot 6 . Sementara itu MCS2_4 512 STA dan MCS2_8 512 STA memiliki nilai delay yang relative stabil. MCS2_4 512 STA pada slot 2 yang memiliki delay terendah yaitu $2171.77 \mathrm{~ms}$.

Gambar 6. Hasil simulasi delay (detik) berdasarkan Jumlah $R A W$
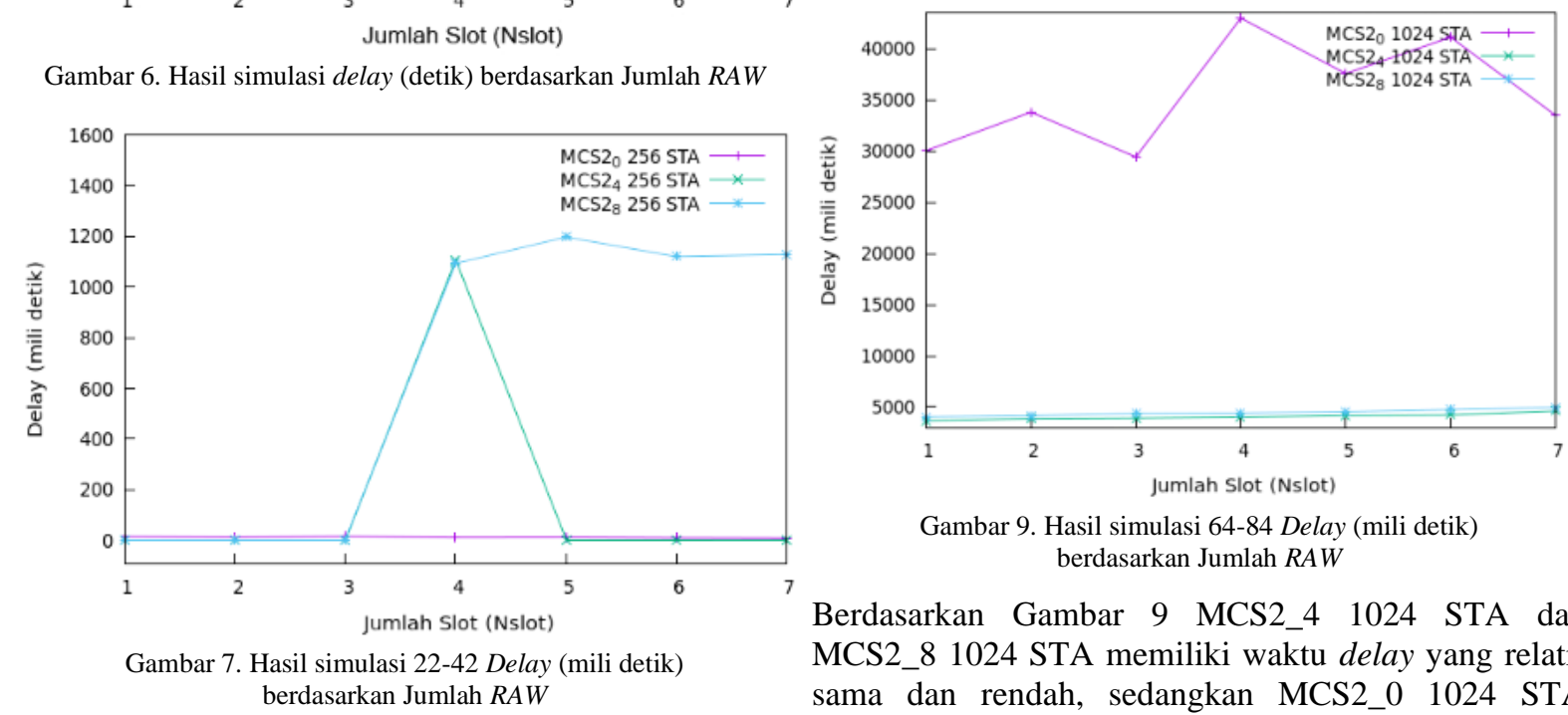

Gambar 9. Hasil simulasi 64-84 Delay (mili detik) berdasarkan Jumlah $R A W$

Berdasarkan Gambar 9 MCS2_4 1024 STA dan MCS2_8 1024 STA memiliki waktu delay yang relatif sama dan rendah, sedangkan MCS2_0 1024 STA memiliki waktu delay yang tinggi terutama pada slot 4

Berdasarkan Gambar 6 dapat dilihat pada MCS2_0 128 STA memiliki delay yang sangat tinggi pada slot 3 dan 4 mencapai $2800 \mathrm{~ms}$. Sementara itu pada slot $3-5$ untuk MCS2_4 128 STA dan MCS2_8 128 STA memiliki waktu delay yang sama yaitu 500ms. Jika dibandingkan pada ketiga data rate diatas, MCS2_8 128 STA memiliki waktu delay yang cenderung stabil pada slot 1-7 dan data rate MCS2_0 128 STA memiliki waktu delay tertinggi yang mencapai $42963.2 \mathrm{~ms}$.

3.3 Pengaruh jumlah slot terhadap packet loss

Pengaruh jumlah slot terhadap packet loss seperti yang diperlihatkan pada Gambar 10 - 13. Packet loss merupakan parameter menggambarkan suatu kondisi yang menunjukan jumlah total paket data yang hilang pada saaat melakukan transmisi data di dalam suatu

DOI: https://doi.org/10.29207/resti.v5i2.2961

Lisensi: Creative Commons Attribution 4.0 International (CC BY 4.0) 
jaringan. Dengan mengunakan sistem operasi linux ubuntu dan aplikasi simulator NS-3 didapatkan hasil sebagai berikut :

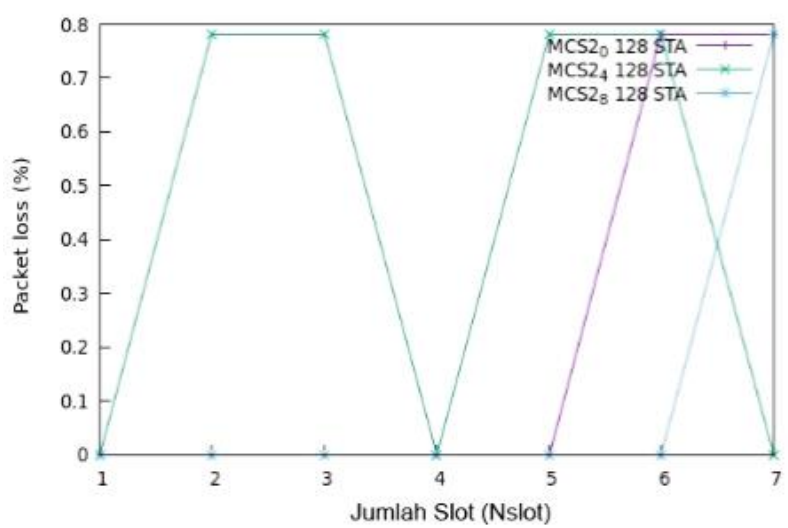

Gambar 10. Hasil simulasi Packet loss (\%) berdasarkan Jumlah RAW

Berdasarkan Gambar 10 data rate MCS2_0 128 STA dan MCS2_8 128 STA memiliki nilai packet loss yang paling rendah yaitu 0\% pada slot 1-5. Pada slot 6 dan 7 pada MCS2_0 128 STA nilai packet loss meningkat drastis sehingga mencapai $0.8 \%$, sedangkan pada MCS2_8 128 STA hanya pada slot 7 nilai packet loss meningkat menjadi $0.8 \%$. Dari ketiga data rate diatas, hanya MCS2_4 128 STA yang tidak stabil.

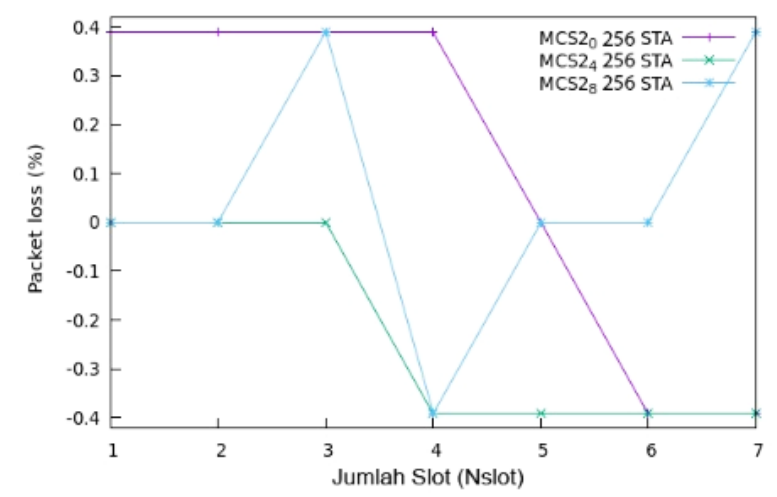

Gambar 11. Hasil simulasi 22-42 Packet loss (\%) berdasarkan Jumlah $R A W$

Berdasarkan Gambar 11 MCS2_0 256 STA slot 1 - 4 dan MCS2_8 256 STA slot 3 dan 7 memiliki packet loss yang paling tinggi yaitu $0.4 \%$. Sementara itu MCS2_0 256 STA slot 6, MCS2_4 256 STA slot $4-7$ dan MCS2_8 256 STA slot 4 memiliki nilai packet loss yang sama dan merupakan yang paling kecil yaitu $-0,4 \%$.

Berdasarkan Gambar 12 MCS2_0 512 STA memiliki persentse packet loss yang tinggi, terutama pada slot 1 yang mencapai $14.2578 \%$. Dua data rate lainnya memiliki persentase packet loss yang relative rendah, yang paling rendah terdapat pada MCS2_4 512 STA pada slot 4 dan 5 yaitu $-0.585938 \%$.

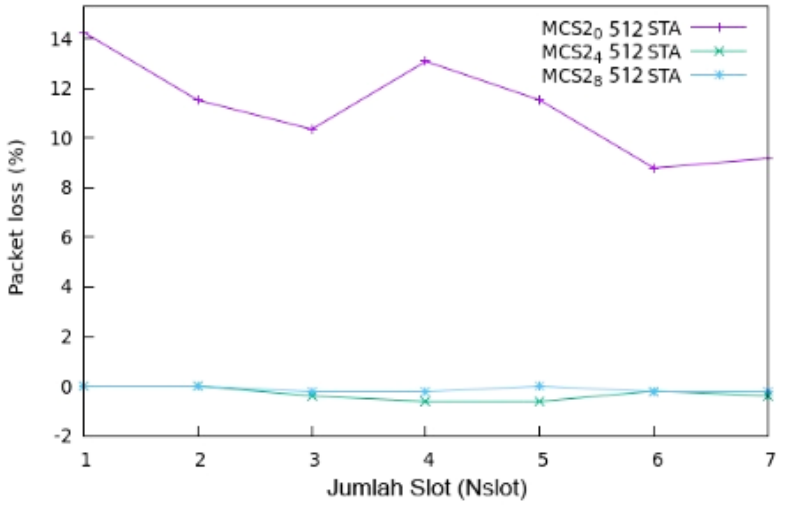

Gambar 12. Hasil simulasi 43-63 Packet loss (\%) berdasarkan Jumlah $R A W$

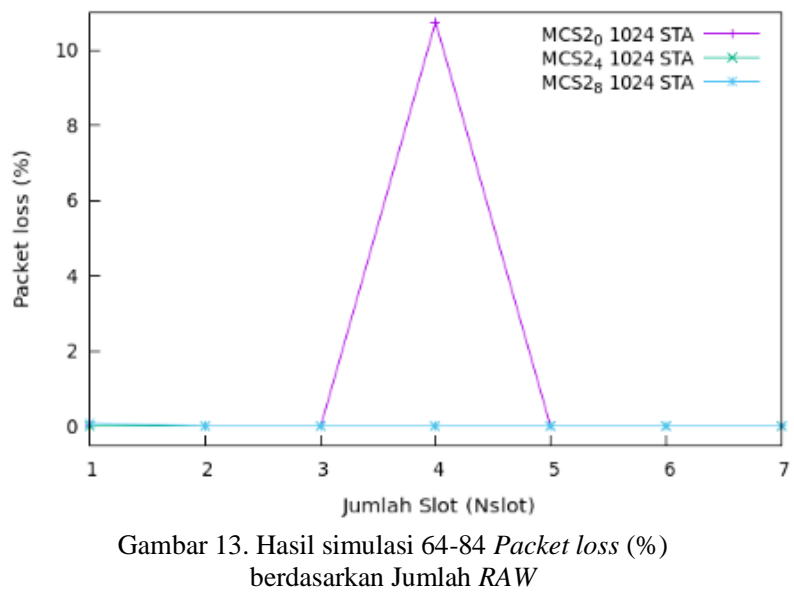

Berdasarkan Gambar 13 ketiga data rate memiliki persentase packet loss yang sama, hanya pada MCS2_0 1024 STA slot 4 yang memiliki persentase packet loss yang tinggi yaitu $10.7422 \%$.

\subsection{Pengaruh jumlah slot terhadap konsumsi energi}

Pengaruh jumlah slot terhadap konsumsi energi seperti yang diperlihatkan pada Gambar 14 - 17. Mengunakan sistem operasi linux ubuntu dengan aplikasi simulator NS-3 mendapatkan hasil sebagai berikut :

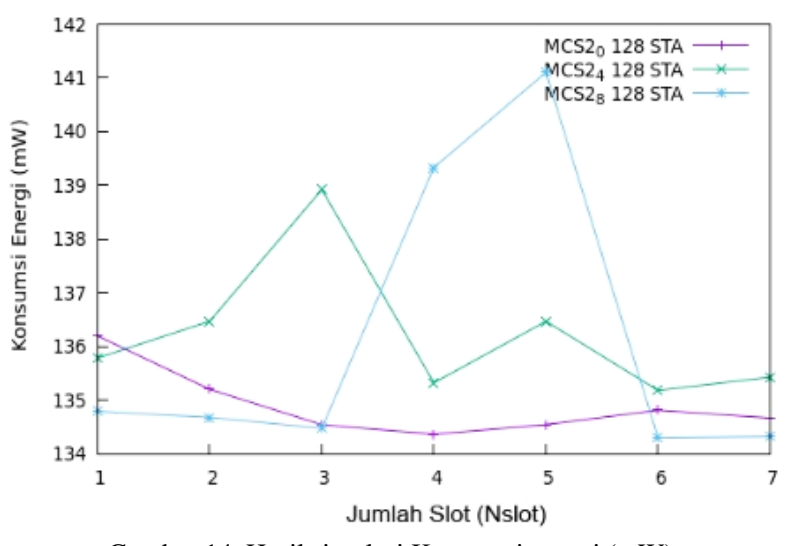

Gambar 14. Hasil simulasi Konsumsi energi (mW) berdasarkan Jumlah $R A W$

DOI: https://doi.org/10.29207/resti.v5i2.2961

Lisensi: Creative Commons Attribution 4.0 International (CC BY 4.0) 
Berdasarkan Gamnar 14 MCS2_8 128 STA memiliki konsumsi energi yang paling besar, sebanyak $141 \mathrm{~mW}$ pada slot 5, namun menurun drastis pada slot 6 dan 7 , dimana konsumsi energi yang dihasilkan sebesar $134 \mathrm{~mW}$. Sementara itu dibandingkan kedua data rate yang lain, MCS2_0 128 STA tergolong memiliki konsumsi energy yang stabil, terutama pada slot $3-7$.

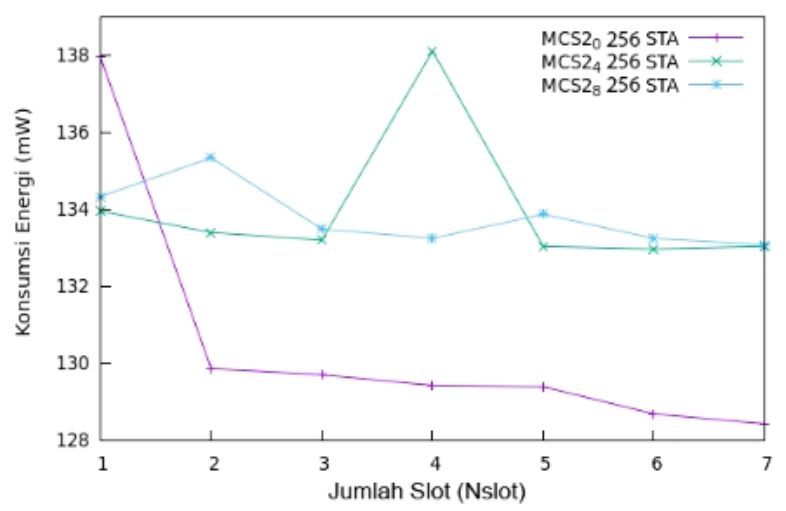

Gambar 15. Hasil simulasi 22-42 Konsumsi energi (mW) berdasarkan Jumlah $R A W$

Berdasarkan Gambar 15 MCS2_0 256 STA slot 1 dan MCS2_4 256 STA slot 4 memiliki konsumsi energi paling besar, sebanyak $138 \mathrm{~mW}$, namun konsumsi energi pada MCS2_0 256 STA berangsur menurun mulai dari slot 2 dan pada slot 7, konsumsi energi MCS2_0 256 STA berkisar $128 \mathrm{~mW}$ dan merupakan konsumsi energi terendah dibandingkan data rate yang lain.

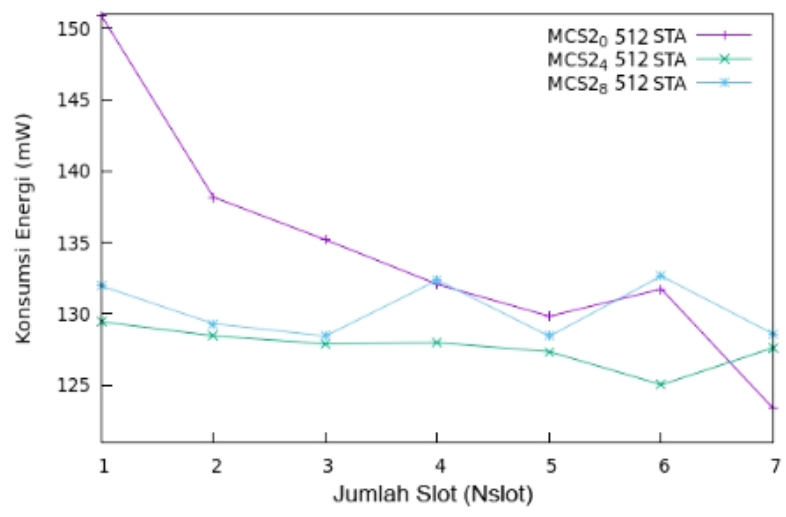

Gambar 16. Hasil simulasi 43-63 Konsumsi energi (mW) berdasarkan Jumlah $R A W$

Berdasarkan Gambar 16 MCS2_0 512 STA memiliki konsumsi energi tertinggi dan juga terendah, dimana slot 1 memiliki konsumsi energy tertinggi yaitu $150.887 \mathrm{~mW}$ dan slot 7 memiliki konsumsi daya paling rendah yaitu $123.365 \mathrm{~mW}$.

Berdasarkan Gambar 17 hanya MCS2_4 1024 STA yang memiliki konsumsi energi yang stabil walau pada slot 1 memiliki konsumsi energi paling tinggi dibanding data rate yang lain yaitu $120.489 \mathrm{~mW}$. Untuk konsumsi energi paling rendah terdapat pada MCS2_0 1024 STA pada slot 3 yaitu $106.735 \mathrm{~mW}$.

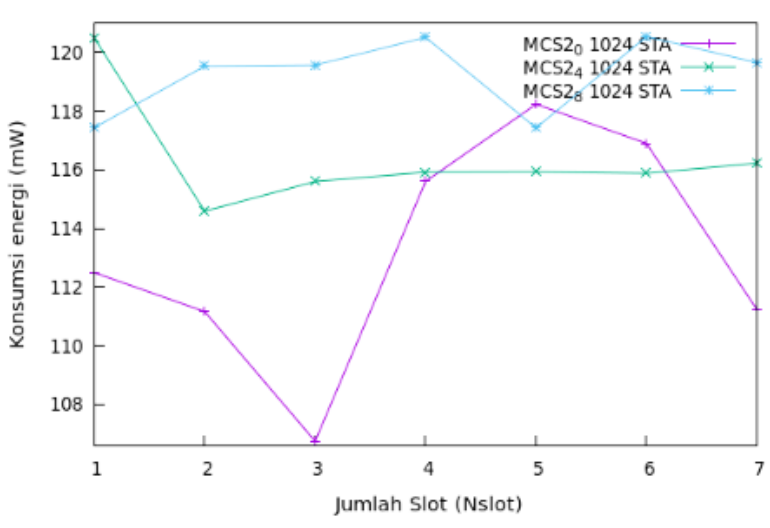

Gambar 17. Hasil simulasi 64-84 Konsumsi energi (mW) berdasarkan Jumlah $R A W$

\section{Kesimpulan}

Setelah melakukan implementasi pengujian, desain pengujian dengan cara mengimplementasikan tahapan Rectricted Access Window berdasarkan Multirate pada IEEE 802.11 ah untuk optimasi kinerja jaringan IoT pada aplikasi simulator NS-3. Kemudian mengevaluasi dan menganalisis hasil simulasi berdasarkan pengaruh Throughput, delay, packet loss dan konsumsi energy yang dihasilkan berdasarkan multirate pada WLAN 802.11ah maka dapat disimpulkan yaitu berdasarkan pengujian pengaruh jumlah slot terhadap throughput pada hasil simulasi menunjukkan nilai throughput yang dihasilkan berubah-ubah pada tiap slot dengan dominasi stabil, tergantung jumlah slot yang digunakan.

Pengaruh jumlah slot terhadap delay memiliki waktu delay yang sama dan cenderung stabil dan beberapa nilai waktu delay juga rendah, rata-rata delay dipengaruhi oleh mekanisme RAW dimana saat paket dikirim belum mendapat kesempatan pada bagian RAW slot. Berdasarkan pengujian pengaruh jumlah slot terhadap packet loss menunjukkan nilai packet loss rendah tiap slot-nya, dikarenakan banyak paket yang dapat ditampung pada antrian $R A W$ slot sehingga sedikit yang dibuang. Pengaruh jumlah slot terhadap konsumsi energi yang dihasilkan pada simulasi menurun pada beberapa data rate dan beberapa nilai konsumsi energi menjadi terendah sehingga menghemat konsumsi energi. Dapat dikatakan makin bertambah jumlah slot mengakibatkan kecepatan mobilitas meningkat, namun nilai rata-rata konsumsi energi hanya naik sedikit. Hasil penelitian ini masih bisa dikembangkan atau digunakan sebagai referensi bagi penelitian berikutnya. Peneliti berikutnya dapat merujuk hasil ini untuk dapat merancang protokol yang sesuai dan dapat menghasilkan kinerja jaringan yang lebih baik pada standar IEEE 802.11ah.

\section{Daftar Rujukan}

[1] L. Tian, E. Lopez-Aguilera, E. Garcia-Villegas, M. T.Mehari, E. De Poorter, S. Latr_e, J. Famaey, Optimization oriented 
RAW modeling of IEEE 802.11ah heterogeneous networks, IEEE Internet of Things Journal, pp. 1328, 2019.

[2] J. Famaey, The long life of iot devices: Comparing the energy consumption of sub-1ghz wireless technologies, accessed: 2020-05-10. URL:

https://www.researchgate.net/publication/338920462 The Long Life of IoT Devices Comparing the Energy Consumption of Sub- $1 \mathrm{GHz}$ Wireless Technologies

[3] V. Baños-Gonzalez, M. S. Afaqui, E. Lopez-Aguilera, E. Garcia-Villegas, "IEEE 802.11ah: A technology to face the IoT challenge", Sensors, vol. 16, no. 11, pp. 1960, 2016.

[4] R. Cahyani, D. Perdana, A. T. Hanuranto, "A Feasibility Analysis of the Use of IEEE 802.11 ah to extend 4G Network Coverage", Buletin Pos dan Telekomunikasi, vol. 18, no.2, pp. 111-126, 2020

[5] IEEE Standard for Information technology-Telecommunications and information exchange between systems - Local and metropolitan area networks--Specific requirements - Part 11: Wireless LAN Medium Access Control (MAC) and Physical Layer (PHY) Specifications Amendment 2: Sub $1 \mathrm{GHz}$ License Exempt Operation," in IEEE Std 802.11ah-2016 (Amendment to IEEE Std 802.11-2016, as amended by IEEE Std 802.11ai-2016), vol., no., pp.1-594, May 52017.

[6] Serpanos D., Wolf M. "The IoT Landscape. In: Internet-ofThings (IoT)" Systems. Springer, Cham, 2018.

[7] E. Khorov, A. Lyakhov and R. Yusupov, "Two-Slot Based Model of the IEEE 802.11ah Restricted Access Window with Enabled Transmissions Crossing Slot Boundaries," 2018 IEEE 19th International Symposium on "A World of Wireless, Mobile and Multimedia Networks" (WoWMoM), Chania, Greece, 2018, pp. 1-9

[8] N. Nawaz, M. Hafeez, S. A. R. Zaidi, D. C. McLernon and M. Ghogho, "Throughput enhancement of restricted access window for uniform grouping scheme in IEEE 802.11ah," 2017 IEEE International Conference on Communications (ICC), Paris, 2017, pp. 1-7.

[9] A. J. Gopinath and B.Nithya, "Mathematical and simulation analysis of contention resolution mechanism for IEEE 802.11ah networks," Computer Communications, pp. 124, 87-100, 2018.
[10] R. Wang and M. Lin, "Restricted Access Window Based Hidden Node Problem Mitigating Algorithm in IEEE 802.11ah Networks," IEICE TRANSACTIONS on Communications, 2018. Article in press.

[11] Y. Wang, K. K. Chai, Y. Chen, J. Schormans and J. Loo, "Energy-Delay Aware Restricted Access Window with Novel Retransmission for IEEE 802.11ah Networks," 2016 IEEE Global Communications Conference (GLOBECOM), Washington, DC, 2016, pp. 1-6.

[12] L. Tian, J. Famaey and S. Latré, "Evaluation of the IEEE 802.11ah Restricted Access Window mechanism for dense IoT networks," 2016 IEEE 17th International Symposium on A World of Wireless, Mobile and Multimedia Networks (WoWMoM), Coimbra, 2016, pp. 1-9.

[13] M. N. Perbawa, D. Permana, Y. G. Bisono, "Performance Analysis of the Differences Restricted Access Window ( $R A W$ ) on IEEE 802.11 ah Standard with Enhanced Distributed Channel Access (EDCA),“ Jurnal Infotel, vol. 10, no. 4, 2018.

[14] Šljivo, A.; Kerkhove, D.; Tian, L.; Famaey, J.; Munteanu, A.; Moerman, I.; Hoebeke, J.; De Poorter, E. Performance Evaluation of IEEE 802.11ah Networks With High-Throughput Bidirectional Traffic. Sensors 2018, 18, 325.

[15] L. Tian, M. Mehariy, S. Santi, S. Latre, "IEEE 802.11ah Restricted Access Window Surrogate Model for Real-Time Station Grouping," Conference paper, June 2018. Aricle in press.

[16] L. Tian, S. Deronne, S. Latre and J. Famaey, "Implementation and Validation of an IEEE 802.11ah Module for ns-3," in Proceedings of the Workshop on ns-3, Seattle, WA, USA, 2016.

[17] Le Tian, Amina Sljivo, Serena Santi, Eli De Poorter, Jeroen Hoebeke, Jeroen Famaey. Extension of the IEEE 802.11 ah NS3 Simulation Module. Workshop on ns-3 (WNS3), 2018.

[18] M. I. Denatama, D. Perdana, dan R. M. N, "Analisis Perbandingan Kinerja Protokol Routing DSDV dan OLSR Untuk Perubahan Kecepatan Mobilitas pada Standar IEEE 802.11ah," Jurnal Infotel, vol. 8, no.2, pp. 100-106, 2016

[19] B. Bellekens, L. Tian, P. Boer, M. Weyn, and J. Famaey. Outdoor IEEE 802.11 ah Range Characterization Using Validated Propagation Models. In GLOBECOM 2017 - 2017 IEEE Global Communications Conference. Singapore. 